\title{
Family Business as a Way of the Entrepreneurship Development in Russia
}

\author{
Submitted 06/06/20, 1st revision 17/07/20, 2nd revision 30/08/20, accepted 15/09/20 \\ Yuliya G. Leskova ${ }^{1}$, Anatoly N. Levushkin ${ }^{2}$,Sergey Yu.Morozov ${ }^{3}$, \\ Valery V. Romanov ${ }^{4}$, Sergey G. Berezhny ${ }^{5}$, Leysan E. Rakhmatullina ${ }^{6}$
}

\begin{abstract}
:
Purpose: Nowadays, the participation of a family and its members in the ownership and management of business is an important and practice-oriented process. Therefore, the purpose of this study is to develop recommendations for improving the legal regulation of family business as a way of improving entrepreneurship in Russia, increasing the level of legal protection of family members in business.

Design/Methodology/Approach:To achieve this purpose the authors used the following general and private scientific methods: dialectical, logical, system and complex analysis, comparative legal, formal legal, statistical and legal modeling methods.

Findings: The article investigates family business as a way of developing entrepreneurship in Russia, possible economic and legal forms of spouses 'business. The authors define the legal nature of family business and the specifics of regulating the legal regime of business assets of spouses, and determine some problems of compliance with the rules basing on the analysis of private law regulation of family business.The paper analyzes the draft law "On amendments to the federal law "On the development of small and medium-sized business in the Russian Federation" for fixing the concept "family enterprise" and further progressive and effective legal regulation of family business in our country. The authors make conclusions on the legal grounds of the spouses' business as an object of law and a form of business.

Practical Implications: The conclusions and the changes in legal regulation proposed by the author are aimed at legislating the ability of citizens to carry out business in the form of a family enterprise, an effective model for organizing a family business, as well as defining the forms of possible state support for this activity.
\end{abstract}

${ }^{1}$ Doctor in Law, Professor, The Head of the Business, Labour and Corporate Law Department of the Institute of Law and National Security, Russian Academy of National Economy and State Administration of the Russian Federation, Moscow, Russian Federation, shok93@yandex.ru;

${ }^{2}$ Professor of the Business, Labour and Corporate Law Department of the Institute of Law and National Security, Russian Academy of National Economy and State Administration of the Russian Federation, Doctor in Law, Professor.

${ }^{3}$ The Head of the Civil and Business Law Department, Dean of law faculty of Ulyanovsk State University, Doctor in Law, Professor.

${ }^{4}$ Professor of the Theory and History of State and Law Department of Ulyanovsk State University, Ulyanovsk, Russian Federation.

${ }^{5}$ Senior lecturer of the Civil Law and Procedure Department of the Belgorod University of Cooperation, Economics and Law, Belgorod, Russian Federation.

${ }^{6}$ The Lecturer-researcher of the Civil and Business Law Department, Ulyanovsk State University, Ulyanovsk, Russian Federation. 
Originality/Value: The conclusions contribute to improve the legal regulation of family entrepreneurship and spouses' business. The conception of family business and family enterprise can become an important anti-crisis legal tool for solving socio-economic, legal and demographic problems of the Russian population, society and the state.

Keywords: Business activity, family business, family enterprise, family relations, entrepreneurship, legal regime of property.

JEL Code: K36, O29.

Paper type: Research article.

Acknowledgment: The research study was carried out as part of the state task of the Russian Academy of National Economy and Public Administration under the President of the Russian Federation No. 5.7 "Family relations and business processes in the context of reforming Russian legislation".

\section{Introduction}

Expanding business opportunities through the new areas of private capital investment, as well as stimulating and supporting the entrepreneurial activity of the population, gradually lead to an increase of business opportunities and the activation of business entities. Nowadays, the domestic economy is approaching a developed market system, in which new forms and types of business activity become important. Therefore, in accordance with current trends in the Russia's economy it is necessary to expand the range of subjects engaged in business activity. One of the most promising types of economic entities is a family business organization.

According to experts, more than $45 \%$ of small and medium-sized business enterprises operate in the form of family business (Ershova et al., 2020). The family business organization complies with the fundamental legal act such as the Constitution of the Russian Federation, which is aimed at special protection of the family, motherhood, fatherhood and childhood (Articles 7, 38) and other family values, the principles of freedom of business, it creates a legal framework for protecting family members' rights in the family business. We wholly agree with V.K. Andreev that family entrepreneurship (business) does not have a capital law (Ershova et al., 2020).

Moreover, the Russian legislation does not include the "family business" concept, its features, rules to inherit business, to pass business by inheritance from older generation to younger one. There are a lot of difficulties connected with this in practice. At the legislative level the question about the relation between norms of the Civil Code of the Russian Federation, Family Code of the Russian Federation, and Federal laws, for instance Federal law from 08.02.1998 № 14-FL "On limited liability companies", Federal law "On peasant (farm) farming" etc. is debatable. 
Scientific discussions about the influence of a family on the business entity has been going on for a long time. However, many organizational, legal and methodological issues are still unresolved. We are wholly agree with Ershova's opinion according to which, Russian legal science has to form the family entrepreneurship conception (Ershova, 2018; Ershova et al., 2020). According to the state family policy conception family and legal conflicts destroy the traditional institution of family and marriage. And this inevitably leads to the leveling of family ties based on the traditional family model.

It seems that the family business should be based on a stable marriage and marital union and family values, including the property interests of spouses and other family members. The family values loss and the destruction of the marriage and marital union may lead to the family breakdown and as a result to the marriage dissolution, and the necessity to determine the marital property, including the family business.

Nowadays, the participation of the family and its members in the ownership and management of business is an important and practice-oriented process, since it fully reflects its sense only when it can significantly influence goals, strategies and organizational structures of business entities.

Thus, for our country with its traditional family values, family entrepreneurship is a very attractive phenomenon. This model of business is reasonable and effective, since it is difficult for a person to make financial investments and to organize business processes alone, and it is not always rational and, of course, risky to involve outsiders in running a common business. Family members can create a favorable economic and legal environment for business. The main socio-economic basis of a modern family business is trust and common economic resources and property interests of all the family members.

\section{Theoretical Foundation and Methodology}

In the civil doctrine, the issues of regulation of family entrepreneurship and family business by spouses, their participation in business processes are discussed from time to time (Ershova et al., 2020). However, within the framework of the scientific speciality 12.00 .03 on this issue, there is only one dissertation (Barkova, 2015), which is devoted to the study of family entrepreneurship.

In Russia during the last period, quite significant scientific events on the development and further improvement of the regulation of family entrepreneurship and business as forms of entrepreneurship in the Russian Federation have been held. There the issues of organizing and modernizing the mechanisms of family business regulation and the harmonious development of family entrepreneurship find their logical solution ${ }^{7}$.

${ }^{7}$ Over the last three years conferences were held: international scientific-practical conference "The Legal ways of the business upon divorce and inheritance", 2018; the international 
The methodological basis of the research is made of general methods such as the dialectical, logical method, the system and complex analysis method, as well as private scientific techniques such as comparative legal, formal legal, statistical and legal modeling methods. These methods use makes it possible to identify significant problems in the family business regulation as a way of the entrepreneurship development in Russia, to find connections between common and private interests, to analyze legal norms, to compare and summarize facts, to determine trends in the regulation of the these relations, and to draw basic conclusions.

\section{Results and Discussion}

During the economic instability, crisis processes in in the economy, and the growing prospects of a new "round" of the global economic crisis, theoretical and applied research in the field of legal security for strengthening and supporting small and medium-sized business in the Russian Federation, as well as the justification to legislate the possibility of implementing the family entrepreneurship conception in the framework of creating a family enterprise on the territory of the Russian Federation is very important. In addition, the status of self-employed citizens also supporting the economy of Russia by their activity is contradictory and needs scientific research and improvement in practice for implementing the family entrepreneurship development conception in the Russian Federation.

A.N. Levushkin is quite right saying: "In the modern period of the Russian legislation development, a new direction is being actively implemented. It is the family legislation publicization, the public legal institutions interference in the issues within the family and marriage" (Levushkin, 2013). Later this opinion of the author was reflected in the Conception of improving the family legislation of the Russian Federation (Expert opinion on the draft Conception). It is necessary to draw an unambiguous conclusion about the mutual penetration of norms and conceptual categories, the unity of the principles of Russian law. This universality makes it possible to apply the family law provisions both to business and corporate legal relations with the only caveat. In addition to relations of kinship and property the necessary criterion for relatives-partners is common joint employment in business, and the distributed income depends on the degree of each family member involvement. At the same time, corporate relationships are personal and confidential.

This guarantees, most often, the conscientiousness of the parties. Professor Yu.G. Leskova reasonably believes that the legal status of participants in legal relations is regulated both by civil and other acts..., which proves the intersectoral sense of legal

scientific and practical conference "Family business: its place in the system of business processes and innovation", 2019; international scientific-practical conference "Family business \& self-employed: a look through the prism of the legal regime of small business" 2020 . 
relations and intersectoral regulation (Leskova, 2017). It is especially clear when building a system of legal regulation of the organization and implementation of business by family members.

It should be noted that family business as an economic and legal phenomenon really exists in the Russian Federation, but this form of business is not provided in Russia's current legislation. The idea of family entrepreneurship has its roots far back in history. In Russia, the "family craft" approach has been historically developed, in which artisans passed all their knowledge and skills from generation to generation, thereby preserving their craft in the family. A new round of such a form of entrepreneurship, including numerous related dynasties of entrepreneurs is a feature of time. Blood-related dynasties with business based on family ties is a feature of the post-reform period of Peter the Great. For example, the Morozov's and Ryabushinsky's merchant dynasties and others.

Having investigated Russian legislation, we should talk about three organizational and legal forms of commercial and non-commercial organizations, which are based on personal-trust, and in some cases family-legal ties: 1) communities of small indigenous peoples; 2) Cossack societies; 3) peasant (farm) farms. The content of these organizational and legal forms looks like the family enterprise conception, but they go far beyond it, since these concepts allow for the existence and the development of business regardless of the family (family business) or even without it. Thus, it is necessary for the society to develop family business but it is faced with the lack of legislative support for this form of business in our country.

It must be admitted that the spouses' business is mainly related to their private life as family members, and it can be characterized as an object of regulation. Of course, marital forms of entrepreneurship are based on trust (fiduciary). A family business in a complex integrated form. It can be defined as an enterprise in absolutely any (permitted by law) form of business organization in the field of economic activity, in which two or more members of the same family take part, or the family and its members own most of the assets or control over the business organization.

Identifying the special features of family entrepreneurship that distinguish it from other forms and types of business it is important to highlight its following constructive points: 1) the so-called family-legal relations that arise between family members; 2) the participation of family members in the family business. The second feature in the aspect of personal labour participation is typical for peasant farming. At the same time, family-legal relations themselves are a criterion for distinguishing family entrepreneurship from other types and forms, including small and medium-sized business in whole.

In our opinion it is reasonable to define the legal nature of the spouses' business as an object of law and a form of business: 
a) the spouses' business is the capital (stocks, shares, units), property complexes, enterprises owned or controlled by the spouses. This includes both small business and public companies based on private ownership.

b) the spouses' business is various forms of business, the organization and the functioning of business models of family entrepreneurship.

It is necessary to define married business processes as a complex economic, legal, and social organized phenomenon and to interpret it as: 1) an economic-legal category; 2) a method and a form of business organization; 3) a comprehensive legal institute in the system of business law, 4) a type of economic behavior of the spouses, as a result of which their property and their capital are formed; 5) a legal form of the realization of the spouses ${ }^{6}$ entrepreneurial potential, based on family-legal relations.

In accordance with the current economic and legal realities in our country, it is possible to distinguish two forms of spouses' business:

- the direct cases in which the business is carried out by the spouses together, for example, when the spouses are members of a peasant farm.

- indirect cases, when one of the spouses carries out the business, the participation (membership) in organizations of one spouse is established, or one of the participants in corporate, mandatory business relations is a spouse- entrepreneur, and the other, not carrying out business activity, is entitled to half of the income from the business and the business itself by virtue of the status of the marriage.

Based on the above, it is reasonable to distinguish the special complex legal regime of the spouses' business. This legal regime is regulated by the norms of business, civil, family, corporate, and constitutional law. The legal regime of the spouses' business is regulated both at the level of private and public law in order to ensure the effective implementation of the spouses' business and the harmonious protection of their rights.

Studying the special legal regime of the spouses' business, it is necessary to pay attention to its special economic nature, since the emerging legal relations are the business relations of the family as a special socio-economic unit of society. The spouses are bound by marriage, which determines the place and significance of such entrepreneurial property relations of the spouses in the system of economic activity and family entrepreneurship. Moreover, it is necessary to pay attention to the ratio of trust and conscientiousnesses of the spouses themselves and their business partners, since trust is built on the belief in the conscientiousnesses and reasonableness of the counterparty.

Elements of a special legal regime of the spouses' business are: a special legal regime of the business spouses, a special procedure for the possession, the use and the disposition of property acquired as a result of the spouses ${ }^{6}$ business implementation, a special procedure of deviding the property acquired as a result of the business (business assets and debts). A special legal regime of the entrepreneurial activity and 
the spouses' business is a combination of special legal norms regulating family entrepreneurship, establishing the specifics of legal regulation for achieving the spouses' business goals, the use of specific legal means, as well as the isolation of legal norms comprehensively regulating the organization and the implementation of spouses' business.

Family entrepreneurship (spouses' business) is considered to be a rather popular type of economic activity, prevailing in quantitative terms in countries with developed market economies. However, the legislation of the Russian Federation still lacks a law that establishes a legal definition of the family entrepreneurship concept and its criteria; features of the legal status of family business entities; measures to support family entrepreneurship.

The Ministry of economic development of the Russian Federation has prepared a draft law "On amendments to the Federal law "On the development of small and mediumsized business in the Russian Federation" in order to fix the "family enterprise" concept. The sense of the legislative plan is to allocate a special target group among small and medium-sized business entities that need additional state support. It is the "family enterprise". For this, a number of amendments are proposed to Federal law No. 209-FL from July 24, 2017 "On the development of small and medium-sized business in the Russian Federation". It is proposed to fix the definitions of "family enterprise" and "family members" in article 3, and to fix the criteria of family enterprises and the conditions for their state support in article 24.2.

The "family enterprise" status gives additional advantages to an economic entity as an anti-crisis tool for solving socio-economic problems, and therefore the state has the right to demand from it a higher degree of socially useful significance of its activity. For example, the logic of a foreign legislator in state support to a social entrepreneur is to encourage such an entrepreneur who guarantees a high degree of usefulness of his/her activity by reinvesting at least half of the profit in solving socio-environmental problems (Barkov and Grishina, 2019). In the Law on social entrepreneurship, the Russian legislator also adheres to this rule. In this connection, we believe that paragraph 1.1 of article 24.2 of the Draft law, needs to be significantly revised in the social aspect or deleted.

In modern social and legal reality, in conditions of constant changes and reformatting of relations in the field of entrepreneurship, the new types of entrepreneurial activity, the special legal regime of spouses' business should be considered as one of the main directions of national economic policy in improving business activity in the Russian Federation, the simplification of doing business in the country (including its starting up). Therefore at the legislative level, it is necessary to provide the ability to model various types of special legal regimes of entrepreneurship using measures of state regulation of entrepreneurial activity, as well as to establish criteria for distinguishing between legal regimes of entrepreneurial activity in Russia. 
Expanding business opportunities through the new areas of private capital investment, as well as stimulating and supporting the entrepreneurial activity of the population, gradually lead to an increase in business opportunities and the activation of business entities and civil turnover to create and participate in the activity of legal entities. However, recent events to counter the threat of the new coronavirus infection (COVID-19) spread in Russia have a negative impact. The need for preventive measures in connection with the coronavirus pandemic in March-May 2020 forced us to take unprecedented measures to prevent the large-scale spread of infection. Measures taken and implemented by the government of the Russian Federation and local executive authorities to prevent an uncontrolled outbreak of the disease have predictably affected the economy and entrepreneurial activity, as well as the effective development of self-employed citizens. And taking into account the fact that preventive measures were most exposed to such areas as health care, services, catering, leisure and entertainment, it seems these areas of business in the future will have serious problems, related to the reduction of income, the non-payment of mandatory payments, taxes, fees, rent payments, the non-payment of wages to employees, etc. It is possible that the business will "go into the shadows".

"Revenue" losses can be so large that they can lead to the termination of some business projects. It means that not only the entrepreneur's activity will be terminated and he/she will not have income from his/her previous business, but this will also entail the dismissal of employees engaged in business. This in turn will cause an increase in the unemployment rate, which negatively affects the economic situation in the country.

The steps taken by the state to increase economic growth and reduce unemployment against the background of the pandemic should be evaluated positively, but the situation that there is no a legalized type of family business leads in some cases to different forms of support for family business. Small and medium-sized types of business may have some forms of support and self-employed persons may have another forms of support.

So, the Federation Council proposed to pay business 18 thousand rubles a month from the budget for each new employee, and to give 100 thousand rubles to the selfemployed person to start his/her own business (Yershova, 2018). However, the family entrepreneurship when one spouse is self-employed, does not exclude participation of other family members in business. It is possible that they do not work as official employees (or they use a civil contract). Therefore, it is necessary to re-emphasize the need to consider such categories as a family enterprise and a family patent, including in relation to self-employed citizens, and expand the conditions for receiving monthly payments to family business, which also can be carried out by self-employed citizens.

\section{Conclusions}

According to our research we can make a conclusion that it is important for improving 
the legal regulation and the state support for family entrepreneurship and family business on the territory of the Russian Federation first of all to fix the "family enterprise" concept at the Federal law level and determine possible measures to support such enterprises in order to ensure their effective functioning. The draft law investigated in this paper proposes to fix the "family enterprise" concept in the Federal law "On the development of small and medium-sized business in the Russian Federation", to define its criteria and functions, but the draft law does not reflect some important features of the conception of the formation and the development of family entrepreneurship, which were justified in doctrinal (theoretical), practical and applied research on this issue.

Summing up the results of the study, we can draw the following conclusions:

1. it seems reasonable to legalize the family business by directly regulating it at the level of a special legislative act, which coincides to the European conception of the development of the family business as an object of legal regulation;

2. in accordance with the initiatives proposed by the law enforcer and the legislator it is important to support a legislative initiative about the "family business" concept legalization. The "family business" like "social enterprise" can be an effective anticrisis legal means of solving socio-economic, legal and demographic problems of the Russian population, society and the state;

3. the authors formulated "spouses' business" concept as a complex economic category, a set of proprietary and some non-material elements for the spouses' rights realization in entrepreneurial activity in various spheres, the incomes of which go to the joint spouses' property.

4. it is important to take into account that the number of subjects of legal relations in the field of the family entrepreneurship includes not only legal entities and individual entrepreneurs (small and medium-sized business). These entities should include selfemployed persons and large business.

5. the authors believe that the issue of unity and exclusion of contradictions between the law and judicial practice is very urgent today. Accordingly, determining the features and conditions for the family enterprise, it is also necessary to clearly fix the legal consequences for the family business of losing the status of a spouse, including fixing at the legislative level the reasons for the former spouse to receive income from the family enterprise (not only in accordance with current legislation, but also taking into account a marriage contract).

6. Family business is based on personal trust, marriage and family relations (ties) of spouses and other family members, therefore, it is necessary at the legislative level to fix for family business the legal consequences of the spouse (family member) status loss, as well as to set the time of loss of such a status. In particular, the authors propose to fix the legal grounds for a former spouse or a family member participated in a family enterprise to claimed a part of the income from the family enterprise;

7. In order to reduce the internal document flow of family enterprises and reduce overhead costs, it is necessary to provide at the legislative level the family patent conception. Family members will be able to carry out legal activity in the family 
enterprise without the need to process a large number of documents and bureaucratic obstacles.

\section{References:}

Barkov, A.V., Grishina, J.S. 2019. Critical analysis of the Russian legislative approach to the legalization of social entrepreneurship. Civil law, 2, 3-5.

Barkova, L.A. 2015. Family entrepreneurship in the mechanism of legal support for the harmonization of family interests. Ph.D. thesis, Moscow, 4-5.

Ershova, I.V. 2018. Microenterprise: "micro" does not mean "small". Business law, 2, 11-18.

Ershova, I.V., Levushkin, A.N., Maksimovich, L.B., Andreev, V.K. 2020. Family business in the legal space of Russia. Moscow, 23-33.

Leskova, Yu.G. 2017. On the optimization of intersectoral relations of inheritance law. Inheritance Law, 1, 13.

Levushkin, A.N. 2013. Theoretical model of building the system of family legislation of the CIS member States. Moscow, 129.

RBC. 2019. Putin suggested clarifying the concept of family business Available online: https://www.rbc.ru/rbcfreenews/5d2c92949a79479d24a034a0. 